\title{
Improvement Grade 4 Science Learning Outcomes with Video Assisted Problem Based Learning Model
}

\section{Eva Fitri Hidayanti}

SD Negeri Watujaran

evapriono02@gmail.com

\section{Article History}

accepted 01/11/2020

\begin{abstract}
This article describes the improvement of students' science learning outcomes by applying a video-assisted problem-based learning model in class IV SD Negeri Watujaran in the 2020/2021 learning year. This study uses three cycles. Where each cycle begins with planning, implementing, observing, and reflecting. The results of this study were that in cycle 1 there was an increase from pre-cycle, 58\% of students were complete and in cycle 2 there was an increase from cycle 1, 91,\% of students were complete, and in cycle 3 the results of students learning completeness reached $100 \%$ of the 12 students. These results indicate that the application of the video-assisted problem-based learning model can improve the science learning outcomes of students at SD Negeri Watujaran.
\end{abstract}

Keyword : learning outcomes, problem based learning, grade 4

\section{Abstrak}

Artikel ini menjelaskan tentang peningkatan hasil belajar IPA peserta didik dengan menerapkan model pembelajaran problem based learning berbantuan video pada kelas IV SD Negeri Watujaran tahun pembelajaran 2020/2021. Penelitian ini menggunakan tiga siklus. Dimana setiap siklusnya dimulai dengan perencanaan, pelaksanaan, observasi, dan refleksi. Hasil dari penelitian ini adalah pada siklus 1 terlihat peningkatan dari pra siklus, 58\% peserta didik tuntas dan pada siklus 2 terlihat peningkatan dari siklus 1,91,\% peserta didik tuntas, dan pada siklus 3 hasil ketuntasan belajar peserta didik mencapai $100 \%$ dari 12 peserta didik. Hasil ini menunjukkan bahwa penerapan model problem based learning berbantuan video dapat meningkatkan hasil belajar IPA peserta didik pada SD Negeri Watujaran.

Kata Kunci : hasil belajar, problem based learning, video

Social, Humanities, and Education Studies (SHEs): Conference Series https://jurnal.uns.ac.id/shes 


\section{PENDAHULUAN}

Dengan diberlakukannya kurikulum 2013 tentu saja guru harus berupaya untuk lebih kreatif lagi dalam mendesain pembelajaran agar tujuan pembelajaran yang hendak dicapai dapat terwujud dengan maksimal. Namun terkadang upaya yag dilakukan belum dapat mencapai hasil yang memuaskan. Seperti halnya dalam kegiatan pembelajaran di kelas IV SD Negeri Watujaran, Korwilcam dindik Sumbang. Dalam kegiatan pembelajaran IPA di kelas IV SD Negeri Watujaran, Korwilcam Dindik Sumbang, berdasar hasil penilaian harian muatan IImu Pengetahuan Alam belum mencapai Ketuntasan belajar 85\%. Tema 4 Berbagai Pekerjaan diperoleh nilai ratarata kelas masih di bawah KKM ditetapkan yaitu sebesar 70 . Dengan rendahnya nilai hasil belajar muatan IImu Pengetahuan Alam (IPA) tema 4 Berbagai Pekerjaan tentu saja menimbulkan keprihatinan saya sebagai guru kelas.

Dengan adanya kesenjangan yang terjadi antara kondisi real dengan harapan yaitu kondisi real nilai hasil belajar muatan IPA pada siswa kelas IV yang rendah . Sedangkan harapan nilai hasil belajar muatan IPA pada siswa kelas IV minimal sama dengan Kriteria Ketuntasan Minimal (KKM), maka perlu dicarikan solusi. guru kelas sebagai pelaku utama dalam pembelajaran tentu tidak boleh tinggal diam dengan adanya kesenjangan yang terjadi. Masih rendahnya hasil belajar siswa tentu saja perlu adayan upaya-upaya yang dilakukan untuk meningkatkan hasil belajar siswa.

Banyak cara yang bisa dilakukan guru untuk meningkatkan hasil belajar siswa, diantaranya dengan memperbaiki suasana belajar, mengubah model dan metoda dalam pembelajaran, penggunaan alat peraga untuk mendukung kegiatan pembelajaran. Merangsang siswa supaya lebih aktif lagi dalam kegiatan pembelajaran.

Menurut Nana Sudjana (2009:3) hasil belajar siswa pada hakikatnya ialah perubahan tingkah laku sebagai hasil belajar dalam pengertian yang lebih luas mencakup bidang kognitif, afektif, dan psikomotorik. Menurut Susanto (2013:5) pengertian hasil belajar adalah perubahan yang terjadi pada diri siswa, baik yang menyangkut aspek kognitif, afektif, dan psikomotor. Menurut Affandi, dkk (2013:7) tujuan hasil belajar adalah mengevaluasi kemampuan yang dimiliki oleh siswa yang mencakup aspek kogniktif, afektif, dan psikomotorik pada mata pelajaran di sekolah dasar setelah melalui proses belajar menggunakan metode pembelajaran. Aspek kognitif yang ditinjukkan dengan kemampuan siswa dalam menyelesaikan ujian tertulis yang berkaitan dengan kehidupan sehari-hari dengan menerapkan pengetahuan yang dimiliki siswa. aspek afektif dan psikomotor yang ditinjau dari sikap siswa pada saat proses pembelajaran.

Pada dasarnya ilmu pengetahuan alam (IPA) atau sains mempelajari mengenai gejala alam beserta isinya sebagaimana adanya, serta terbatas pada pengalaman manusia. Dan dalam usaha menafsirkan gejala alam tersebut manusia berusaha untuk mencari penjelasan tentang berbagai kejadian, penyebab, serta dampak yang ditimbulkan dengan menggunakan metode ilmiah. Metode ilmiah inilah yang merupakan jembatan antara penjelasan secara teoritis dengan pembuktian secara empiris (Sujana, 2013, hlm 25).

I Gusti Ayu Tri Agustiana(2014: 435) menambahkan bahwa dalam proses pembelajaran IPA, keempat unsur (sikap, proses, produk, dan aplikasi) diharapkan dapat muncul sehingga peserta didik dapat mengalami proses pembelajaran secara utuh, memahami fenomena alam melalui kegiatan pemecahan masalah, metode ilmiah, dan meniru cara ilmuwan bekerja dalam menemukan fakta baru. Menurut Kemendiknas (2011: 3) pembelajaran IPA adalah suatu pendekatan yang menghubungkan atau menyatupadukan berbagai bidang kajian IPA menjadi satu kesatuan bahasan. Sitiatava (2013: 53) berpendapat bahwa pembelajaran berbasis sains adalah proses transfer ilmu dua arah antara guru (sebagai pemberi informasi) dan siswa (sebagai penerima informasi) dengan metode tertentu (proses sains). 
Menurut Ridwan (2015 : 127) Problem Based Learning (PBL) merupakan pembelajaran yang penyampainnya dilakukan dengan cara menyajikan suatu permasalahan, mengajukan pertanyaan- pertanyaan, memfasilitasi penyelidikan, dan membuka dialog. Menurut Duch dalam Aris Shoimin (2014: 130) menyatakan bahwa Problem Based Learning (PBL) atau Pembelajaran Berbasis Masalah (PBM) adalah model pengajaran yang bercirikan permasalahan nyata sebagai konteks untuk para peserta didik belajar berpikir kritis dan keterampilan memecahkan masalah serta memperoleh pengetahuan. Menurut Finkle dan Top dalam Aris Shoimin (2014: 130) menyatakan bahwa Problem Based Learning merupakan pengembangan kurikulum dan sistem pengajaran yang mengembangkan secara stimultan strategi pemecahan masalah dan dasar- dasar pengetahuan dan ketrampilan dengan menempatkan peserta didik dalam peran aktif sebagai pemecahan masalah sehari- hari yang terstruktur dengan baik.

Dari pendapat diatas dapat disimpulkan bahwa model Problem Based Learning (PBL) merupakan model pembelajaran yang bercirikan suasana pembelajaran yang diarahkan oleh suatu permasalahan sehari- hari sebagai konteks siswa dalam berpikir kritis dalam memecahkan suatu masalah serta memperoleh pengetahuan. Permasalahan dalam model pembelajaran ini dapat diajukan dari guru kepada siswa, dari siswa kepada guru atau dari siswa itu sendiri, yang kemudian dijadikan pembahasan dan dicari pemecahannya sebagai kegiatan- kegiatan belajar siswa.

Menurut Rudi (2008:19) video adalah serangkaian gambar diam (still picture) yang meluncur secara cepat dan diproyeksikan sehingga menimbulkan kesan hidup dan bergerak. Sedangkan menurut Arsyad $(2004 ; 36)$ yang dikutip oleh Rusman $(2012 ; 218)$ mengemukakan video merupakan serangkaian gambar gerak yang disertai suara yang membentuk satu kesatuan yang dirangkai menjadi sebuah alur, dengan pesan-pesan di dalamnya untuk ketercapaian tujuan pembelajaran yang disimpan dengan proses penyimpanan pada media pita atau disk.

Menurut Sukiman (2012:187), video mampu menampilkan gambar bergerak atau gambar hidup dengan disertai suara. Secara empiris, kata video berasal dari sebuah singkatan yang dalam bahasa inggris yaitu audio dan visual. Kata vi adalah singkatan visual yang berarti gambar, kemudian pada kata Deo adalah singkatan dari audio yang artinya suara.

Dari beberapa pendapat ahli mengenai pengertian media video pembelajaran adalah seperangkat komponen atau media yang mampu menampilkan gambar sekaligus suara dalam waktu bersamaan. Pada dasarnya hakikat video adalah mengubah suatu ide atau gagasan menjadi sebuah tayangan gambar dan suara yang proses perekamannya dan penayangannya melibatkan teknologi tertentu

\section{METODE}

Penelitian ini menggunakan penelitian tindakan kelas yang merupakan tindakan reflektif oleh aktor untuk meningkatkan proses pembelajaran. Penelitian Tindakan Kelas adalah refleksi dari kegiatan belajar dalam bentuk tindakan, yang

sengaja diangkat dan terjadi di kelas secara bersamaan. Tindakan diberikan oleh guru atau oleh arahan guru yang dibuat oleh peserta didik (Fuad and Hamam 2012; Fuad and Winarsih 2018). PTK dapat dikatakan berhasil jika peserta didik telah belajar banyak bukan berapa banyak guru bertindak. Model riset ini mencakup empat tahap tindakan yaitu perencanaan, tindakan, observasi dan refleksi. (A. Jauhar Fuad \& Ananda Dwi Permatasari, 2019 : 66).

Penelitian ini dilakukan 3 siklus. Siklus pertama dilaksanakan pada tanggal 22 Oktober 2020 dan siklus ke 2 dilaksanakan pada tanggal 2 November 2020 dan siklus 3 pada 13 November 2020. Subjek dari penelitian ini adalah Peserta didik Kelas II SD Negeri Watujaran Semester 1 Tahun Pelajaran 2020/2021 dengan jumlah peserta didik sebanyak 12. 
Data kuantitatif dalam bentuk prestasi belajar kognitif, dianalisis menggunakan teknik analisis deskriptif dengan menentukan rerata. Data kuantitatif akan disajikan sebagai persentase. Data kualitatif disajikan dalam kalimat yang dipisahkan oleh kategori untuk mendapatkan kesimpulan. Data kualitatif ini diperoleh dari mengolah data yang diperoleh dari instrumen pengamatan aktivitas peserta didik atau instrumen pengamatan keterampilan guru.

\section{HASIL DAN PEMBAHASAN}

Sebelum melakukan siklus, peneliti melakukan proses pembelajaran dengan menggunakan metode ceramah dan tanya jawab dengan materi pelestarian sumber daya alam, ketuntasan belajar dari materi yang diajarkan dengan KKM 70 hanya 1 peserta didik (8\%) sedangkan yang tidak tuntas ada 11 peserta didik $(92 \%)$.

Pada kegiatan pra siklus terlihat hasil yang diperoleh siswa masih jauh dari standar prosentase ketuntasan klasikal sebesar $85 \%$ belum memenuhi standar. Terlihat dari hasil belajar bahwa masih banyak peserta didik yang nilainya dibawah KKM. Siklus I ini dilaksanakan pada tanggal 22 Oktober 2020 dan tanggal 23 Oktober 2020. Pada siklus 1 guru menggunakan model pembelajaran problem based learning berbantuan video untuk dapat meningkatkan kemampuan belajar peserta didik. Pada kegiatan inti, guru menampilkan video pelestarian lingkungan dengan materi pelestarian hutan, kemudian peserta didik berdiskusi menyelesaikan permasalahan yang berhubungan dengan pelestarian hutan. Pada siklus 1 diperoleh hasil sebagai berikut :

Tabel 2. Hasil Belajar Peserta didik Siklus I

\begin{tabular}{l|c|c|c|c}
\hline \multirow{2}{*}{} & \multicolumn{4}{|c}{ Siklus I1 } \\
\cline { 2 - 5 } & \multicolumn{2}{|c|}{ Pertemuan 1 } & \multicolumn{2}{c}{ Pertemuan 2 } \\
\cline { 2 - 5 } & Pre test & Post Test & Pre Test & Post Test \\
\hline Pesdik Tuntas & 1 & 3 & 5 & 7 \\
Pesdik Tidak tuntas & 11 & 9 & 7 & 5 \\
\hline
\end{tabular}

Dari nilai di atas ketuntasan belajar dari 12 peserta didik dengan KKM 70 pada akhir pertemuan siklus I ada 7 peserta didik (58\%) yang tuntas. Sedangkan yang tidak tuntas ada 5 peserta didik (42\%). Pada siklus 1 rata rata kelas yang diperoleh adalah 69 . Dari data tersebut terdapat kenaikan dari $8 \%$ peserta didik yang tuntas pada pra siklus menjadi $58 \%$ yang tuntas pada siklus I. Akan tetapi hasil pelaksanaan siklus I belum dapat mencapai ketuntasan klasikal yang telah ditentukan yaitu $85 \%$ maka dilaksanakan siklus II.

Pada siklus I setelah guru menggunakan model PBL berbantuan video peserta didik sudah mengalami peningkatan. Hanya saja masih ada beberapa peserta didik yang asih mengalami kesulitan. Sesuai dengan hasil refleksi siklus I di atas maka diadakan perbaikan tindakan kelas siklus II pada IPA materi Pelsetarian Sumber daya alam kelas IV SD Negeri Watujaran Kec. Sumbang Kab. Banyumas semester 1 tahun pelajaran 2020/2021 diharapkan dapat meningkatkan hasil belajar peserta didik, guru menyampaikan materi dan memberi stimulus permasalahan dengan berbantuan video agar peserta didik antusias dan tertarik serta dapat lebih memahami materi yang diajarkan. Dalam Siklus II ini dilakukan pada tanggal 2 November 2020. Berikut adalah hasil dari siklus II. 
Tabel 3 Hasil Belajar Peserta didik Siklus II

\begin{tabular}{l|cc|c|c}
\hline \multirow{2}{*}{} & \multicolumn{4}{c}{ Siklus I1 } \\
\cline { 2 - 5 } & \multicolumn{2}{|c}{ Pertemuan 1 } & \multicolumn{2}{c}{ Pertemuan 2 } \\
\cline { 2 - 5 } & Pre test & Post Test & Pre Test & Post Test \\
\hline Pesdik Tuntas & 5 & 8 & 8 & 11 \\
Pesdik Tidak tuntas & 7 & 4 & 4 & 1 \\
\hline
\end{tabular}

Dari nilai di atas ketuntasan belajar dari materi yang diajarkan dengan KKM 70 ada 11 peserta didik (92\%) yang tuntas. Sedangkan yang tidak tuntas da 1 peserta didik (8\%). Rata rata kelas pada siklus ini adalah 81,5 . Penilaian hasil pada siklus II menunjukkan guru sudah dapat memeningkatkan hasil belajar peserta didik dengan mengunakan model pembelajaran Problem based learning berbantuan video.

Akan tetapi untuk lebih menguji keberhasilan penerapan model pembelajaran problem based learning berbantuan video yang telah terbukti di siklus II maka dilaksanakan siklus III pada tanggal 13 November 2020.

Pada pelaksanaan siklus III yang bertujuan menguji penerapan model PBL apakah benar-benar dapat meningkatkan hasil belajar peserta didik. Pengujian ini terbukti berhasil dapat meningkatkan hasil belajar dengan melihat tabel tabel siklus III di bawah ini.

Tabel 4 Hasil Belajar Peserta didik Siklus III

\begin{tabular}{l|cc|c|c}
\hline \multirow{2}{*}{} & \multicolumn{4}{|c}{ Siklus I1 } \\
\cline { 2 - 5 } & \multicolumn{2}{|c}{ Pertemuan 1 } & \multicolumn{2}{c}{ Pertemuan 2 } \\
\cline { 2 - 5 } & Pre test & Post Test & Pre Test & Post Test \\
\hline Pesdik Tuntas & 5 & 8 & 8 & 12 \\
Pesdik Tidak tuntas & 7 & 4 & 4 & 0 \\
\hline
\end{tabular}

Dari nilai di atas ketuntasan belajar dari materi yang diajarkan dengan KKM 70 ada 12 peserta didik (100\%) yang tuntas. Rata rata kelas pada siklus ini adalah 82,5. Tabel di atas membuktikan dengan beberapa tindakan yang dilakukan guru terutama penerapan model PBL berbantuan video dapat meningkatkan motivasi untuk aktif dan pemahaman terhadap materi sehingga terjadi peningkatan hasil belajar di kelas IV SD Negeri Watujaran Kec. Sumbang Kab. Banyumas semester 1 tahun pelajaran 2020/2021 pada tingkat ketuntasan yang diinginkan dan dapat meningkatkan prestasi belajar peserta didik sebagaimana yang telah direncanakan.

Sesuai dengan teori yang dikembangkan oleh Barrow, Min Liu dalam Aris (2014: 130) menjelaskan karakteristik dari Problem Based Learning (PBL), yaitu Learning is student- centered Proses pembelajaran dalam PBL lebih menitikberatkan kepada sisswa sebagai orang belajar. Oleh karena itu, PBL didukung juga oleh teori kontruktivisme dimana siswa di dorong untuk dapat mengembangakan pengetahuannya sendiri. New information is acquaired through self- directed learning Dalam proses pemecahan masalah mungkin saja siswa belum mengetahui dan memahami pengetahuan prasyaratnya sehingga siswa berusaha untuk mencarai sendiri melalui sumbernya, baik dari buku atau informasi lainnya. Learning accurs small grups Agar terjadi interaksi ilmiah dan tukar menukar pemikiran dalam usaha membangun pengetahuan secara kolaboratif, PBM dilaksanakan dalam kelompok kecil. Kelompok yang dibuatn menuntut pembagian tugas yang jelas dan penetapan tujuan yang jelas. Teachers act as fasiltator Pada pelaksanaan PBM guru hanya berperan sebagai fasilitator. Meskipun begitu guru harus selalu memantau perkembangan aktivitas siswa dan mendorong mereka agar mencapai target yang hendak dicapai. 


\section{SIMPULAN}

Penerapan model pembelajaran Problem Based Learning (PBL) dapat meningkatkan hasil belajar peserta didik Kelas IV pada mupel IPA materi Pelestarian Sumber Daya Alam. Peningkatan hasil belajar yang terjadi karena kesan pembelajaran yang mendalam dari peserta didik terhadap materi yang diajarkan melalui latihan penyelesaian masalah yang dapat melatih peserta didik untuk menyelesaikan masalah dan dapat menunjang peningkatan hasil belajar siswa. Berdasarkan penelitian yang telah dilaksanakan salah satu model pembelajaran yang harus dikuasi guru adalah PBL karena model pembelajaran ini sesuai dengan pembelajaran abad 21 yang sangat cocok diterapkan dalam keadaan pandemi seperti sekarang ini.

\section{DAFTAR PUSTAKA}

Afandi, dkk. (2013). Model dan Metode Pembelajaran di Sekolah. Semarang: Unnisulla Press

Andiani Duri, dkk. (2012). Metode Penelitian. Jakarta: Universitas Terbuka

Anitah, dkk. (2008). Strategi Pembelajaran di SD. Jakarta: Universitas Terbuka Hamalik, Oemar. 2009. Proses Belajar Mengajar. Bumi Aksara. Jakarta

Hardini dan Puspitasari. (2012). Strategi Pembelajaran Terpadu (Teori, Konsep, dan Implementasi). Yogyakarta: Familia

Mulyasa. (2008). Standar Kompetensi dan Sertifikasi Guru. Bandung: Remaja Rosdakarya

Mulyasa, E. (2010). Kurikulum Tingkat Satuan Pendidikan Sebuah Panduan Praktis. Bandung:Remaja Rosdakarya

Shoimin, Aris. (2014). 68 Model Pembelajaran Inovatif dalam Kurikulum 2013. Yogyakarta: Ar- Ruzz Media.

Wardani dan Wihardit. (2009). Penelitian Tindakan Kelas. Jakarta: Universitas Terbuka

Zona Referensi. (2018, 18 Maret) Pengertian Hasil Belajar. Diakses pada 13 Oktober 2020 dari https://www.zonareferensi.com/pengertian-hasil- belajar/ 